\title{
Study on Melt Structure and Viscosity Properties of $\mathrm{CaO}-\mathrm{MgO}-\mathrm{SiO}_{2}-\mathrm{Al}_{2} \mathrm{O}_{3}-\mathrm{TiO}_{2}-\mathrm{FeO}-\mathrm{Cr}_{2} \mathrm{O}_{3}$ system
}

\author{
Weijun Huang ${ }^{1}$, Yajing Liu ${ }^{1 *}$ and Dong $\mathrm{Xu}^{2}$ \\ ${ }^{1}$ College of Materials Science and Engineering, Hebei University of Engineering, China \\ ${ }^{2}$ Hebei Technological Innovation Center for High Quality Cold Heading Steel, Hebei University of Engineering, China
}

Submission: November 16, 2020; Published: December 08, 2020

*Corresponding author: Yajing Liu, College of Materials Science and Engineering, Hebei University of Engineering, China

\begin{abstract}
The viscosity and structure properties of $\mathrm{CaO}-\mathrm{MgO}-\mathrm{SiO}_{2}-\mathrm{Al}_{2} \mathrm{O}_{3}-\mathrm{TiO}_{2}-\mathrm{FeO}-\mathrm{Cr}_{2} \mathrm{O}_{3}$ system are investigated to illuminate the melt properties of $\mathrm{Cr}_{2} \mathrm{O}_{3}$-bearing $\mathrm{BF}$ vanadium slag. The viscosity decreases to $1.5 \mathrm{~Pa} \cdot \mathrm{s}$ at the temperature above $1565 \mathrm{~K}$ for the $\mathrm{CaO}-\mathrm{MgO}-\mathrm{SiO}_{2}-\mathrm{Al}_{2} \mathrm{O}_{3}-\mathrm{TiO}_{2}$ system, the polymerization degree is low due to the main structures of silicate and as monomer. With the introduction of $1.5 \mathrm{wt} \% \mathrm{Cr}_{2} \mathrm{O}_{3}$ and $5 \mathrm{wt} \% \mathrm{FeO}$ into $\mathrm{CaO}-\mathrm{MgO}-\mathrm{SiO}_{2}-\mathrm{Al}_{2} \mathrm{O}_{3}-\mathrm{TiO}_{2}$ system, the viscosity significantly increases and decreases to $1.5 \mathrm{~Pa} \cdot \mathrm{S}$ until temperature beyond $1640 \mathrm{~K}$ due to that part of the chromium forms spinels, and the polymerization degree is drastically enhanced. With further increasing $10 \mathrm{wt} \% \mathrm{FeO}$ into the $\mathrm{CaO}-\mathrm{MgO}-\mathrm{SiO}_{2}-\mathrm{Al}_{2} \mathrm{O}_{3}-\mathrm{TiO}_{2}-1.5 \mathrm{wt} \% \mathrm{Cr}_{2} \mathrm{O}_{3}$ system, the viscosity decreases and is $1.5 \mathrm{~Pa} \cdot \mathrm{s}$ at about $1620 \mathrm{~K}$, the polymerization degree deceases and spinels disappear to improve the viscosity of slag. In general, when existing an amount of $\mathrm{FeO}$ and $\mathrm{TiO}_{2}$ in the slag, the polymerization degree and the viscosity decrease due to a decrease of as a chain structure and an increased number of discrete Si-O-Ti and Ti-O-Ti structures. But the polymerization degree drastically increases with $\mathrm{Cr}_{2} \mathrm{O}_{3}$ introduction due to the formation of $\mathrm{Cr}-\mathrm{O}-\mathrm{Cr}$ in chain structures and the high meltingpoint spinels to increase the viscosity of the system.
\end{abstract}

Keywords: $\mathrm{Cr}_{2} \mathrm{O}_{3}$-bearing $\mathrm{BF}$ vanadium slag; viscosity; polymerization degree; structure

\section{Introduction}

Vanadium, as one of the most important alloying elements, is widely used in metallurgy, chemical engineering and aerospace due to its ability to enhance mechanical properties, such as tensile strength, hardness, and fatigue resistance [1-4]. With the gradual increase of special steel production in the $21^{\text {st }}$ century, vanadium demand is rapidly increasing due to that $85 \%$ vanadium is added as alloying elements in the special steels used in automobiles, ships and spacecraft [5-7]. Natural vanadium mainly exists as vanadium-titanium magnetite (VTM), which is one kind of characteristic resource in China, South Africa, Russia, and America [8-10]. Generally, VTM is reduced in a blast furnace to produce vanadium-bearing hot metal, which is then pre-oxidized in a vanadium-extraction converter (VEC) by blowing oxygen to obtain semi-steel and vanadium-bearing slag, and then the vanadiumbearing slag is treated by the sodium roasting and leaching to obtain $\mathrm{V}_{2} \mathrm{O}_{5}[11,12]$. With the gradual consumption of high quality VTM, the low-grade chromium-bearing VTM (namely Hongge type V-bearing titanomagnetite, with an approximate composition of $45.5 \mathrm{wt} \% \mathrm{TFe}, 10.6 \mathrm{wt} \% \mathrm{TiO} 2,0.4 \mathrm{wt} \% \mathrm{~V}_{2} \mathrm{O}_{5}$, and $0.2 \mathrm{wt} \% \mathrm{Cr}_{2} \mathrm{O}_{3}$ ) $[8,11,12]$ has caused much attention and is beginning to be used by industrial production. It is reported that the proven reserves of Hongge type V-bearing titanomagnetite are over 2.0 billion tons only in Panxi and Chengde regions of China [10-12]. However, when existing $\mathrm{Cr}_{2} \mathrm{O}_{3}$ in the raw materials, the softening and melting properties of pellet and sinter, the properties of the slag (such as the melting temperature, viscosity, molten structure) significantly change during the vanadium-reduction process, which can change the position of the cohesive zone and dropping zone in the BF and deteriorate the dynamics condition to affect permeability index, coke ratio, the yield ratio of elements as well as BF smooth operation [13-18]. Therefore, studying the influence of $\mathrm{Cr}_{2} \mathrm{O}_{3}$ on the properties of $\mathrm{CaO}-\mathrm{MgO}-\mathrm{SiO}_{2}-\mathrm{Al}_{2} \mathrm{O}_{3}-\mathrm{TiO}_{2}-\mathrm{FeO}-\mathrm{Cr}_{2} \mathrm{O}_{3}$ system slag is very crucial to understand the change of the physicochemical properties in cohesive zone and dropping zone for improving the smelting technology and the yield ratio of elements during the vanadium-reduction process from the chromium-bearing VTM in the BF [19-23].

Many studies on the properties of the slag with $\mathrm{CaO}-\mathrm{SiO}_{2}-$ $\mathrm{TiO}_{2}$ system have been carried out to promote the use of VTM in blast furnaces. $[23,23]$ The properties of $\mathrm{FeO}-\mathrm{SiO}_{2}-\mathrm{V}_{2} \mathrm{O}_{3}-\mathrm{TiO}_{2}-\mathrm{Cr}_{2} \mathrm{O}_{3}$ systems have also been reported to study the effect of $\mathrm{Cr}_{2} \mathrm{O}_{3}$ and $\mathrm{TiO}_{2}$ on the yield of vanadium during the vanadium-extraction process in the converter.[3,4] Besides, the $\mathrm{Al}_{2} \mathrm{O}_{3}-\mathrm{CaO}-\mathrm{Cr}_{2} \mathrm{O}_{3}$ system has been studied to obtain a high yield ratio of chromium 
during stainless steel smelting [24-28]. However, few studies on the properties of the slag with $\mathrm{CaO}-\mathrm{SiO}_{2}-\mathrm{Al}_{2} \mathrm{O}_{3}-\mathrm{MgO}-\mathrm{TiO}_{2}-\mathrm{FeO}$ system, especially the $\mathrm{Cr}_{2} \mathrm{O}_{3}$-bearing system slag of $\mathrm{CaO}-\mathrm{MgO}$ $\mathrm{SiO}_{2}-\mathrm{Al}_{2} \mathrm{O}_{3}-\mathrm{TiO}_{2}-\mathrm{FeO}-\mathrm{Cr}_{2} \mathrm{O}_{3}$ have been reported. Meanwhile, the composition of $\mathrm{Cr}_{2} \mathrm{O}_{3}$-bearing $\mathrm{BF}$ vanadium slag is different from that of converter slag and traditional blast furnace slag (Table 1), which leads to the different physicochemical properties of the slag $[29,30]$. With the increase of $\mathrm{TiO}_{2}$ and $\mathrm{Cr}_{2} \mathrm{O}_{3}$ in the slag, spinels can form and strongly affect physicochemical properties of BF slag such as melting temperature, viscosity and crystallization ability, which will cause instability and even problems during the smelting process. The physicochemical properties of melts strongly depend on the structure characteristics which are closely related to the polymerization degree of melts. Thus, it is necessary to study the structure properties of the chromium-bearing BF vanadium slag to expound the relation between macroscopic characteristic and microscopic structure, which is benefit to improving the smelting process of the low-grade chromium-bearing VTM. Therefore, in this study, the viscosity and structure of the $\mathrm{CaO}-\mathrm{MgO}_{-}-\mathrm{SiO}_{2}$ $\mathrm{Al}_{2} \mathrm{O}_{3}-\mathrm{TiO}_{2}-\mathrm{FeO}-\mathrm{Cr}_{2} \mathrm{O}_{3}$ system with different contents of $\mathrm{Cr}_{2} \mathrm{O}_{3}$ and $\mathrm{FeO}$ are investigated using the rotating cylinder method and Raman spectroscopy, respectively. The purpose of this study is to illuminate the structure information of the $\mathrm{Cr}_{2} \mathrm{O}_{3}$-bearing $\mathrm{BF}$ vanadium slag and establish its relationship with the viscosity of slag for optimizing the vanadium-reduction process $[25,31,32]$.

Table 1: Typical chemical compositions of different slag, wt $\%$.

\begin{tabular}{|c|c|c|c|c|c|c|c|c|c|c|}
\hline Species of slag & $\mathbf{C a O}$ & $\mathbf{M g O}$ & $\mathbf{S i O}$ & $\mathbf{F e O}$ & $\mathbf{A l}_{\mathbf{2}} \mathbf{O}_{\mathbf{3}}$ & $\mathbf{M n O}$ & $\mathbf{T i O}_{\mathbf{2}}$ & $\mathbf{C r}_{\mathbf{2}} \mathbf{O}_{\mathbf{3}}$ & $\mathbf{V}_{\mathbf{2}} \mathbf{O}_{\mathbf{3}}$ & $\mathbf{P}_{\mathbf{2}} \mathbf{O}_{\mathbf{5}}$ \\
\hline BF slag & 39.89 & 12.73 & 36.23 & 2.86 & 4.92 & 2.14 & 0 & 0 & 0 & 1.23 \\
\hline Converter slag & 46.92 & 8.99 & 17.96 & 17.73 & 3.73 & 1.68 & 1.23 & 0 & 0 & 1.76 \\
\hline $\mathrm{Cr}_{2} \mathrm{O}_{3}$-bearing vanadium slag & 2.43 & 2.32 & 14.41 & 35.47 & 2.35 & 9.13 & 8.28 & 11.18 & 14.43 & 0 \\
\hline $\mathrm{Cr}_{2} \mathrm{O}_{3}$-bearing BF vanadium slag & 38.12 & 9.98 & 32.98 & 1.1 & 10.63 & 0.26 & 5.32 & 0.39 & 0.25 & 0.97 \\
\hline
\end{tabular}

\section{Experimental}

Reagent grade powders of $\mathrm{CaCO}_{3}(>99.50 \mathrm{wt} \%), \mathrm{MgO}(>99.50$ wt\%), $\mathrm{Al}_{2} \mathrm{O}_{3}(>99.50 \mathrm{wt} \%), \mathrm{Cr}_{2} \mathrm{O}_{3}(>99.50 w t \%), \mathrm{FeC}_{2} \mathrm{O}_{4}(>99.50$ $w t \%), \mathrm{TiO}_{2}(>99.50 \mathrm{wt} \%)$, and high purity $\mathrm{SiO}_{2}(>99.99 \mathrm{wt} \%)$ are used as raw materials. These seven kind powders are dried at 473 $\mathrm{K}$ for 4 hours in a drying oven to remove moisture, and then are well mixed in ball mill in the required proportion according to the actual components of the $\mathrm{Cr}_{2} \mathrm{O}_{3}$-bearing $\mathrm{BF}$ vanadium slag as shown in (Table 2) (with external adding of $\mathrm{FeO}$ and $\mathrm{Cr}_{2} \mathrm{O}_{3}$ ). Then the mixed powders are pressed into tablet samples and heated at $1823 \mathrm{~K}$ for $2 \mathrm{~h}$ in a corundum crucible to prepare pre-melted slag under Ar gas flowing atmosphere (purity of $99.999 \mathrm{vol} \%$, a flow of $400 \mathrm{ml} \cdot \mathrm{min}^{-1}$ ). After heating, a sample is rapidly taken out from the furnace and quenched by water to avoid the oxidation of elements during the cooling process. In addition, during the heating process, the sample is held at $873 \mathrm{~K}$ for $1 \mathrm{~h}$ and $1073 \mathrm{~K}$ for $1 \mathrm{~h}$ to decarburize $\mathrm{FeC}_{2} \mathrm{O}_{4}$ and $\mathrm{CaCO}_{3}$.

Table 2: Typical chemical composition (with external addition of $\mathrm{FeO}$ and $\mathrm{Cr}_{2} \mathrm{O}_{3}$ ) of the studied system slag, wt\%.

\begin{tabular}{|c|c|c|c|c|c|c|c|}
\hline $\begin{array}{c}\text { Sample } \\
\text { No. }\end{array}$ & $\mathbf{C a O}$ & $\mathbf{S i O 2}$ & $\mathbf{A l}_{2} \mathbf{O}_{3}$ & $\mathbf{M g O}$ & $\mathbf{T i O}_{2}$ & $\mathbf{F e O}$ & $\mathbf{C r}_{2} \mathbf{O}_{3}$ \\
\hline 1 & 37.07 & 31.99 & 10.31 & 9.68 & 10.95 & 0 & 0 \\
\hline 2 & 37.07 & 31.99 & 10.31 & 9.68 & 10.95 & 0 & 1.5 \\
\hline 3 & 37.07 & 31.99 & 10.31 & 9.68 & 10.95 & 1.5 \\
\hline 4 & 37.07 & 31.99 & 10.31 & 9.68 & 10.95 & 10 & 1.5 \\
\hline 5 & 37.07 & 31.99 & 10.31 & 9.68 & 10.95 & 10 & 3 \\
\hline
\end{tabular}

After completion of the pre-melting process, $150 \mathrm{~g}$ of the pre-melted sample is put into a corundum crucible and heated in a rotatory viscometer under high-purity Ar gas [29,30]. When reaching the target temperature, it is maintained for more than 30 min to homogenize the molten slag. Subsequently, the molybdenum bob is immersed in liquid slag for $10 \mathrm{~mm}$ and rotated at a fixed speed of $180 \mathrm{r} / \mathrm{min}$, the viscosity of slag is measured at different temperatures (with temperature step of $5 \mathrm{~K}$ ) during temperature dropping process. The schematic illustration of a rotatory viscometer and the dimension of crucible and a molybdenum bob are shown in Figure 1. In addition, calibration measurements of the apparatus are carried out at room temperature using a standard oil of known viscosity before measuring the viscosity [33,34]. In order to clarify the effects of $\mathrm{Cr}_{2} \mathrm{O}_{3}$ and $\mathrm{FeO}$ on the structure characteristics of the $\mathrm{CaO}-\mathrm{SiO}_{2}-\mathrm{Al}_{2} \mathrm{O}_{3}-\mathrm{MgO}-\mathrm{TiO}_{2}-\mathrm{FeO}-\mathrm{Cr}_{2} \mathrm{O}_{3}$ system slag, $8 \mathrm{~g}$ of the pre-melted slag is placed in a corundum crucible (with inner diameter of $15 \mathrm{~mm}$ and height of $20 \mathrm{~mm}$ ) for molten state in a resistance furnace at approximately $1823 \mathrm{~K}$ for 2 hours under high-purity Ar gas, and then a sample is also quenched in water to form the homogeneous glass. In addition, the samples 
are rapidly taken out from the furnace and quenched by water. The whole process of taking out sample and quenching takes less than $5 \mathrm{~s}$ and water temperature is lower than $298 \mathrm{~K}$ to avoid any precipitation in glass phase during the cooling process [35].

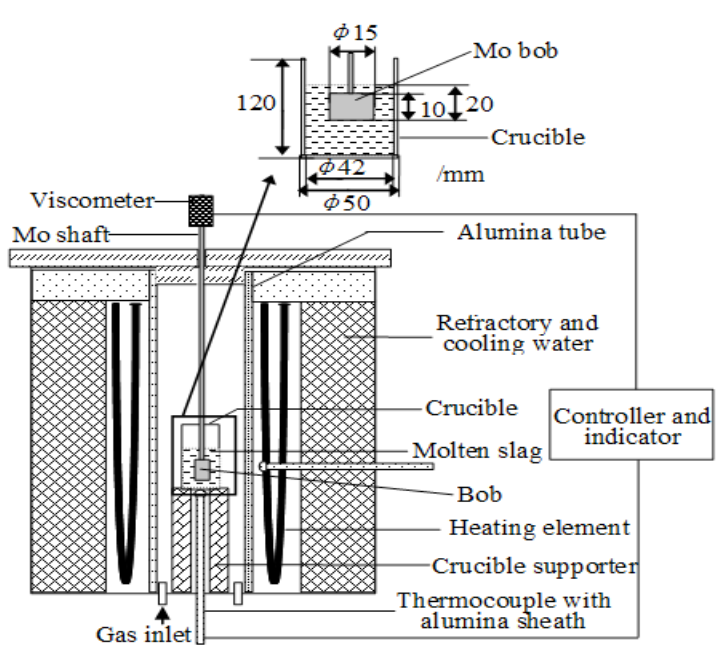

Figure 1: Schematic illustration of the apparatus for viscosity measurements.

The quenched slags are characterized by mineralogical phases, microstructures, and structural properties. The mineralogical phases are examined by X-ray powder diffraction (XRD; X'pert PRO, PANalytical, Netherlands) using $\mathrm{Cu} K \alpha 1$ radiation $(\lambda=1.5406$ $\AA)$ with a step of $0.02^{\circ}(2 \theta)$ and scanning rate of $2^{\circ} \mathrm{min}^{-1}$ in a range of $10^{\circ}$ to $90^{\circ}$. The microstructures, as well as a compositional analysis of the phases in the samples, are determined by scanning electron microscopy (SEM; SSX-550, Shimadzu, Japan) with an attached energy dispersive X-ray analyzer (EDX). The structural properties are analyzed by Raman spectroscopy (Horiba Jobinyvon HR800) using an excitation wavelength of $633 \mathrm{~nm}$ with the laser power of $2 \mathrm{mw}$ at room temperature in the frequency range of $50-2000 \mathrm{~cm}^{-1}$. To be reminded, five different sites in a sample are tested to verify the accuracy of the results. In addition, the spectra of Raman are fitted by assuming Gaussian line shapes for the peaks of different structural units.

\section{Results and Discussion}

\section{Viscosity Property of Slags with $\mathrm{CaO}-\mathrm{SiO}_{2}-\mathrm{Al}_{2} \mathrm{O}_{3}-\mathrm{MgO}$ - $\mathrm{TiO}_{2}-\mathrm{FeO}-\mathrm{Cr}_{2} \mathrm{O}_{3}$ System}

The curves of viscosity versus temperature with different contents of $\mathrm{Cr}_{2} \mathrm{O}_{3}$ and $\mathrm{FeO}$ are shown in Figure 2. It is observed that the viscosity of all the samples first decreases rapidly and then decreases gradually with increasing the temperature, and finally it is close to a constant value. Due to that $\mathrm{Cr}_{2} \mathrm{O}_{3}$-bearing $\mathrm{BF}$ vanadium slag is low basicity slag, the inflection values of viscosity change gradually compared to the basic slag. The inflection values are different with various compositions at different temperatures, it is about $1.3 \mathrm{~Pa} \cdot \mathrm{s}$ for sample 1 at $1570 \mathrm{~K}$, about $1.3 \mathrm{~Pa} \cdot \mathrm{s}$ for sample 2 at $1600 \mathrm{~K}$, about $1.0 \mathrm{~Pa} \cdot \mathrm{s}$ for sample 3 at $1660 \mathrm{~K}$, about $1.1 \mathrm{~Pa} \cdot \mathrm{s}$ for sample 4 at $1630 \mathrm{~K}$, but about $1.3 \mathrm{~Pa} \cdot \mathrm{s}$ for sample 5 at $1695 \mathrm{~K}$, respectively. In addition, the viscosity is decreased with increasing the temperature due to the depolymerization of the complex polymers in molten slag $[30,35]$. When finishing the depolymerization of the complex polymers, the simple structures with high stability in the molten slag are generated at a certain temperature range, the viscosity is close to a constant value $[30,36]$. Consequently, the constant value is different for different component samples. It is observed from Figure 2 that the value is about $0.35 \mathrm{~Pa} \cdot \mathrm{s}$ for sample 1 at temperature above $1740 \mathrm{~K}$, about $0.45 \mathrm{~Pa} \cdot \mathrm{s}$ for sample 2 at temperature above $1745 \mathrm{~K}$, about 0.55 $\mathrm{Pa} \cdot \mathrm{s}$ for sample 3 at temperature above $1745 \mathrm{~K}$, and about 0.47 $\mathrm{Pa} \cdot \mathrm{s}$ for sample 4 at temperature above $1740 \mathrm{~K}$, and about 0.86 $\mathrm{Pa} \cdot \mathrm{s}$ for sample 5 at temperature above $1750 \mathrm{~K}$, respectively. For the traditional BF smelting, the slag viscosity is required to be 1.5 $\mathrm{Pa} \cdot \mathrm{s}$ at about $1600 \mathrm{~K}$, which is beneficial to working smoothly and enhancing BF operation [30,35,36]. The critical temperatures for the viscosity decreasing to $1.5 \mathrm{~Pa} \cdot \mathrm{s}$ are $1565 \mathrm{~K}, 1585 \mathrm{~K}, 1640 \mathrm{~K}$, $1620 \mathrm{~K}$ and $1680 \mathrm{~K}$ for sample 1 , sample 2, sample 3, sample 4 and sample 5 respectively, which indicates that the viscosity of the samples significantly increases with increasing the $\mathrm{Cr}_{2} \mathrm{O}_{3}$ content in this system, but complexly changes with introduction of $\mathrm{FeO}$.

\section{Raman Spectroscopy}

All original spectra for glassy samples with different contents of $\mathrm{Cr}_{2} \mathrm{O}_{3}$ and $\mathrm{FeO}$ are shown in Figure 3. It is observed that the 
dominant peak of the Raman spectrum for the slag with $\mathrm{CaO}-\mathrm{SiO}_{2}-$ $\mathrm{Al}_{2} \mathrm{O}_{3}-\mathrm{MgO}-\mathrm{TiO}_{2}$ system in sample 1 is at about $850 \mathrm{~cm}^{-1}$. With the introduction of $1.5 \mathrm{wt} \% \mathrm{Cr}_{2} \mathrm{O}_{3}$ into this system for sample 2 , the shape and position of dominant peak of the Raman spectrum slightly change. With the introduction of $1.5 \mathrm{wt} \% \mathrm{Cr}_{2} \mathrm{O}_{3}$ and $5 \mathrm{wt} \%$ $\mathrm{FeO}$ into the $\mathrm{CaO}-\mathrm{SiO}_{2}-\mathrm{Al}_{2} \mathrm{O}_{3}-\mathrm{MgO}-\mathrm{TiO}_{2}$ system for sample 3 , the relative intensity of the main band at about $850 \mathrm{~cm}^{-1}$ is reduced by more than $50 \%$, but the peak width obviously increases. With further introduction $10 \mathrm{wt} \% \mathrm{FeO}$ in the $\mathrm{CaO}-\mathrm{SiO}_{2}-\mathrm{Al}_{2} \mathrm{O}_{3}-\mathrm{MgO}-\mathrm{TiO}_{2}$ $-1.5 \mathrm{wt} \% \mathrm{Cr}_{2} \mathrm{O}_{3}$ system for the sample 4 , the band at about $850 \mathrm{~cm}^{-1}$ nearly disappears, but the relative intensity of band at about 700 $\mathrm{cm}^{-1}$ becomes stronger. With further increasing $\mathrm{Cr}_{2} \mathrm{O}$ to $3 \mathrm{wt} \%$ in the $\mathrm{CaO}-\mathrm{SiO}_{2}-\mathrm{Al}_{2} \mathrm{O}_{3}-\mathrm{MgO}-\mathrm{TiO}_{2}-10 \mathrm{wt} \% \mathrm{FeO}-1.5 \mathrm{wt} \% \mathrm{Cr}_{2} \mathrm{O}$ system for sample 5 , the relative intensity of band at $900 \sim 1050 \mathrm{~cm}^{-1}$ becomes stronger and its peak width increases.

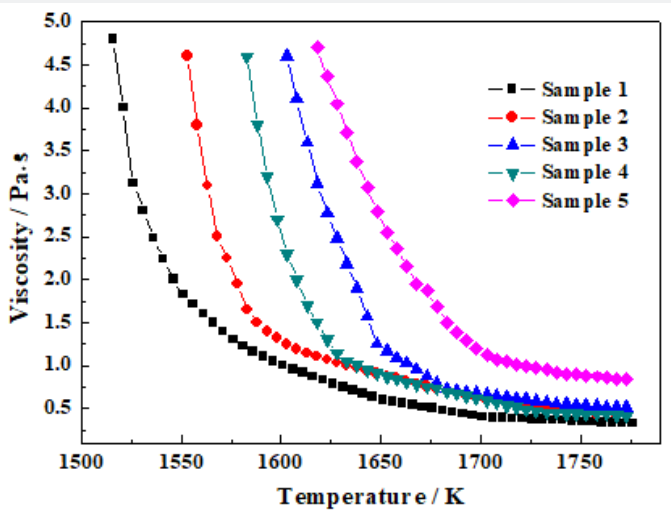

Figure 2: The viscosity of the $\mathrm{BF}$ vanadium slag with various of content of $\mathrm{FeO}$ and $\mathrm{Cr}_{2} \mathrm{O}_{3}$ at given temperatures.

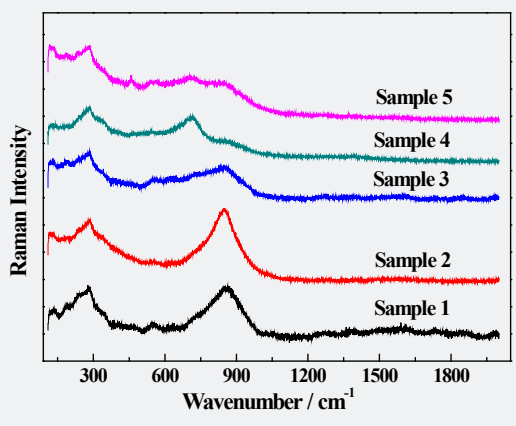

Figure 3: Original Raman spectra for quenched samples with different contents of $\mathrm{FeO}$ and $\mathrm{Cr}_{2} \mathrm{O}_{3}$ at room temperature.

\section{Phase Compositions and Microstructure}

Figure 4 shows the XRD patterns of the quenched samples with different $\mathrm{Cr}_{2} \mathrm{O}_{3}$ and $\mathrm{FeO}$ contents. For the sample 1 without $\mathrm{Cr}_{2} \mathrm{O}_{3}$ and $\mathrm{FeO}$ addition, the crystal phases are not detected, which indicates that the slag with $\mathrm{CaO}-\mathrm{SiO}_{2}-\mathrm{Al}_{2} \mathrm{O}_{3}-\mathrm{MgO}-\mathrm{TiO}_{2}$ system completely melts and does not form any spinels. In addition, with only introduction of a small amount of $\mathrm{Cr}_{2} \mathrm{O}_{3}(1.5 \mathrm{wt} \%)$ in the system for sample 2, the XRD patterns hardly change and new phases don't form in slag. With introduction of the $5 \mathrm{wt} \% \mathrm{FeO}$ in the $\mathrm{CaO}-\mathrm{SiO}_{2}-\mathrm{Al}_{2} \mathrm{O}_{3}-\mathrm{MgO}-\mathrm{TiO}_{2}-1.5 \mathrm{wt} \% \mathrm{Cr}_{2} \mathrm{O}_{3}$ system for sample 3, the composite spinel phase $\left((\mathrm{Mg}, \mathrm{Fe})(\mathrm{Cr}, \mathrm{Al})_{2} \mathrm{O}_{4}\right)$ and $\mathrm{Ca}_{3} \mathrm{Mg}\left(\mathrm{SiO}_{4}\right)_{2}$ generate. With further increasing of $\mathrm{w}(\mathrm{FeO})$ to $10 \mathrm{wt} \%$ in the $\mathrm{CaO}-$ $\mathrm{SiO}_{2}-\mathrm{Al}_{2} \mathrm{O}_{3}-\mathrm{MgO}-\mathrm{TiO}_{2}-1.5 \mathrm{wt} \% \mathrm{Cr}_{2} \mathrm{O}_{3}-5 \mathrm{wt} \% \mathrm{FeO}$ system for sample
4, the high-melting crystal phases disappear. On this basis, with further increasing $\mathrm{w}\left(\mathrm{Cr}_{2} \mathrm{O}_{3}\right)$ to $3 \mathrm{wt} \%$ in the $\mathrm{CaO}-\mathrm{SiO}_{2}-\mathrm{Al}_{2} \mathrm{O}_{3}-\mathrm{MgO}$ $\mathrm{TiO}_{2}-1.5 \mathrm{wt} \% \mathrm{Cr}_{2} \mathrm{O}_{3}-10 \mathrm{wt} \% \mathrm{FeO}$ system for sample 5 , the spinel phase appears again and changes from $(\mathrm{Mg}, \mathrm{Fe})(\mathrm{Cr}, \mathrm{Al})_{2} \mathrm{O}_{4}$ to $\mathrm{Fe}(\mathrm{Al}, \mathrm{Cr})_{2} \mathrm{O}_{4}$, and the peaks intensity of spinel becomes stronger than that of sample 3 .

To further investigate the effect of $\mathrm{Cr}_{2} \mathrm{O}_{3}$ and $\mathrm{FeO}$ on the microstructure of the molten slag, SEM/EDX is employed for the microstructure and compositional analysis of phases on the polished surface of the quenched sample 5, as shown in Figure 5. It is observed that the coexisting phases are composed of liquid phase and spinel phase, which is consistent with the results of X-ray diffraction analysis. In the $\mathrm{CaO}-\mathrm{SiO}_{2}-\mathrm{Al}_{2} \mathrm{O}_{3}-\mathrm{MgO}-\mathrm{TiO}_{2}-3 \mathrm{wt} \% \mathrm{Cr}_{2} \mathrm{O}_{3}-$ 
10 wt\% FeO system, $\mathrm{CaO}, \mathrm{SiO}_{2}, \mathrm{TiO}_{2}, \mathrm{MgO}$ and part of $\mathrm{Cr}_{2} \mathrm{O}_{3}, \mathrm{FeO}$, $\mathrm{Al}_{2} \mathrm{O}_{3}$ form a homogenous liquid phase as shown in Figure 5(c). In addition, some of $\mathrm{FeO}$ can react with $\mathrm{Cr}_{2} \mathrm{O}_{3}$ and $\mathrm{Al}_{2} \mathrm{O}_{3}$ to form the composite spinel $\left(\mathrm{Fe}(\mathrm{Al}, \mathrm{Cr})_{2} \mathrm{O}_{4}\right)$ as shown in Figure $5(\mathrm{~b})$, which will significantly improve the viscosity of slag. Meanwhile, it can also know from Figures $4 \& 5$ that the low melting-point solids (olivine and feldspar) are not found in the quenched samples, thus it is considered that the precipitation of crystal phases is avoided during the quenching process $[30,36]$.

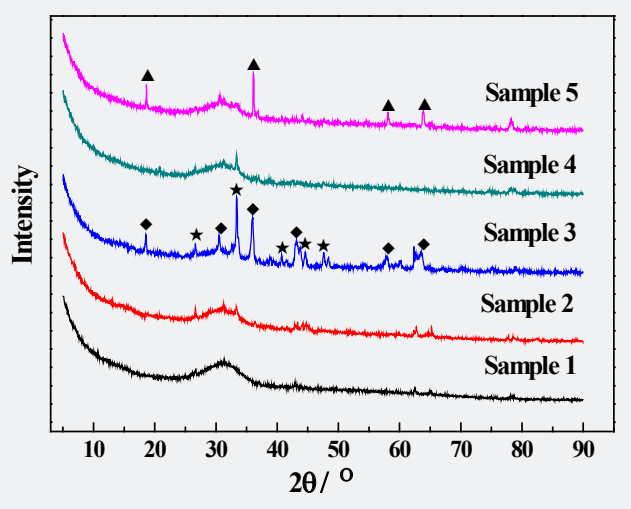

Figure 4: XRD pattern of the quenched sample.
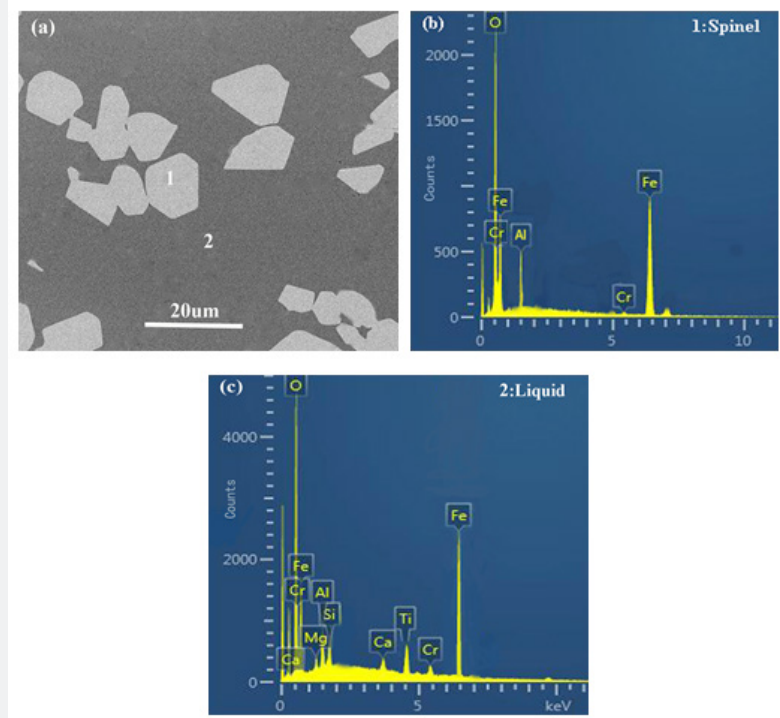

Figure 5: Microstructure and energy spectrum of the phases in sample 4. (a) SEM; (b) 1:Spinel; (c) 2:Liquid.

\section{Discussion}

The different Raman bands are related to the differentstructure units, as summarized in Table 3. According to previous studies for silicate glasses, the low wavenumber regions (below $600 \mathrm{~cm}^{-1}$ ) are assigned to the vibrations such as the bending motions of Si-O-Si angles, the breathing modes of three-and four-membered rings, and the motions of the metal cations [15,25,31,37,38]. Around $780 \mathrm{~cm}^{-1}$, a peak may appear in certain glass compositions and has been attributed to the motions of Si against its tetrahedral oxygen cage [39-41]. The high wavenumber region at about $850-1060 \mathrm{~cm}^{-1}$ mainly characterizes the stretching vibration modes of $\mathrm{Si}-\mathrm{O}$ bond in the $\mathrm{SiO}_{4}^{4-}$ tetrahedron, and corresponds to the silicate sites for the $\mathrm{Q}^{0}, \mathrm{Q}^{1}, \mathrm{Q}^{2}$, and $\mathrm{Q}^{3}$ structure units (superscripts $0,1,2$ and 3 represent the numbers of bridging oxygen per $\mathrm{SiO}_{4}^{4-}$ tetrahedron) $[25,31]$. The bands at about $600-750 \mathrm{~cm}^{-1}$ are attributed to the structural units of titanium in the melts, but $830-850 \mathrm{~cm}^{-1}$ are attributed to Ti-O-Si structure which forms due to $\mathrm{Ti}^{4+}$ substituting $\mathrm{Si}^{4+}$ in tetrahedron [25,31]. The bands at about $690-710 \mathrm{~cm}^{-1}$ and $730-750 \mathrm{~cm}^{-1}$ are assigned to the structural units of chromium in melts $[26,32,42-44]$. As the alkaline oxides in molten slag form 


\section{Academic Journal of Polymer science}

the metal cations $\left(\mathrm{Ca}^{2+}, \mathrm{Fe}^{2+}, \mathrm{Mg}^{2+}, \mathrm{Mn}^{2+}\right)$ with smaller radius for a certain system and hardly affect the structural properties of slag, therefore the wavenumber region of the metal cations will not discuss in the following analysis. Considering that the structural behavior of anions is different in the different system slag, the subsequent work should investigate the structural behavior of various anion and solid oxides in $\mathrm{CaO}-\mathrm{SiO}_{2}-\mathrm{Al}_{2} \mathrm{O}_{3}-\mathrm{MgO}-\mathrm{TiO}_{2}-\mathrm{Cr}_{2} \mathrm{O}_{3}-$ FeO system slag.

Table 3: Assignments of bands in Raman spectra for $\mathrm{CaO}-\mathrm{SiO}_{2}-\mathrm{Al}_{2} \mathrm{O}_{3}-\mathrm{MgO}-\mathrm{TiO}_{2}-\mathrm{Cr}_{2} \mathrm{O}_{3}-\mathrm{FeO}$ system. $\mathrm{MO} \cdot \mathrm{M}_{2}^{\prime} \mathrm{O}_{3}$

\begin{tabular}{|c|c|c|}
\hline Raman centered shift / $\mathrm{cm}^{-1}$ & Raman assignment & References \\
\hline $420-440$ & Antisymmetric stretching vibrations of $\mathrm{Cr}-\mathrm{O}-\mathrm{Cr}$ & {$[15,32]$} \\
\hline $540,635 \sim 730$ & Spinel of $\mathrm{FeCr}_{2} \mathrm{O}_{4}$ and $\mathrm{MgCr}_{2} \mathrm{O}_{4}$ & [43] \\
\hline $540-700$ & Spinels $\left(\mathrm{MO} \cdot \mathrm{M}_{2}^{\prime} \mathrm{O}_{3}\right)$ & [43] \\
\hline $600-750$ & O-Si-O and $\mathrm{O}-\mathrm{Ti}-\mathrm{O}$ deformation vibration & {$[25]$} \\
\hline $730-750$ & Symmetric stretching vibrations of $\mathrm{Cr}-\mathrm{O}-\mathrm{Cr}$ & {$[26,32]$} \\
\hline $690-710$ & Vibrations of V-O-V structure group & {$[31,42]$} \\
\hline $840-850$ & Symmetric $\mathrm{Cr}-\mathrm{O}$ mode of $\mathrm{CrO}_{4}^{2-}$ containing compound & {$[25,31]$} \\
\hline $830-850$ & Vibrations of Ti-O-Si or Ti-O-Ti structure groups, or both & {$[25,31]$} \\
\hline $850-880$ & $\mathrm{SiO}_{4}^{4-}$ with zero bridging oxygen in a monomer structure $\left(\mathrm{Q}^{0}\right)$ & {$[25,31]$} \\
\hline $900-930$ & $\mathrm{Si}_{2} \mathrm{O}_{7}^{6-}$ with one bridging oxygen in dimmer structure unit $\left(\mathrm{Q}^{1}\right)$ & {$[25,31]$} \\
\hline $950-980$ & $\mathrm{Si}_{2} \mathrm{O}_{6-}^{4-}$ with two bridging oxygen in chain structure unit $\left(\mathrm{Q}^{2}\right)$ & {$[25,31]$} \\
\hline $1040-1060$ & $\mathrm{Si}_{2} \mathrm{O}_{5}^{2-}$ with one bridging oxygen in sheet structure unit $\left(\mathrm{Q}^{3}\right)$ & {$[25,31]$} \\
\hline \multicolumn{3}{|c|}{$\mathrm{M}=\mathrm{Mg}, \mathrm{Fe}, \mathrm{Mn}$, eta.: $\mathrm{M}^{\prime}=\mathrm{Al}, \mathrm{Cr}, \mathrm{V}$, etc. } \\
\hline
\end{tabular}
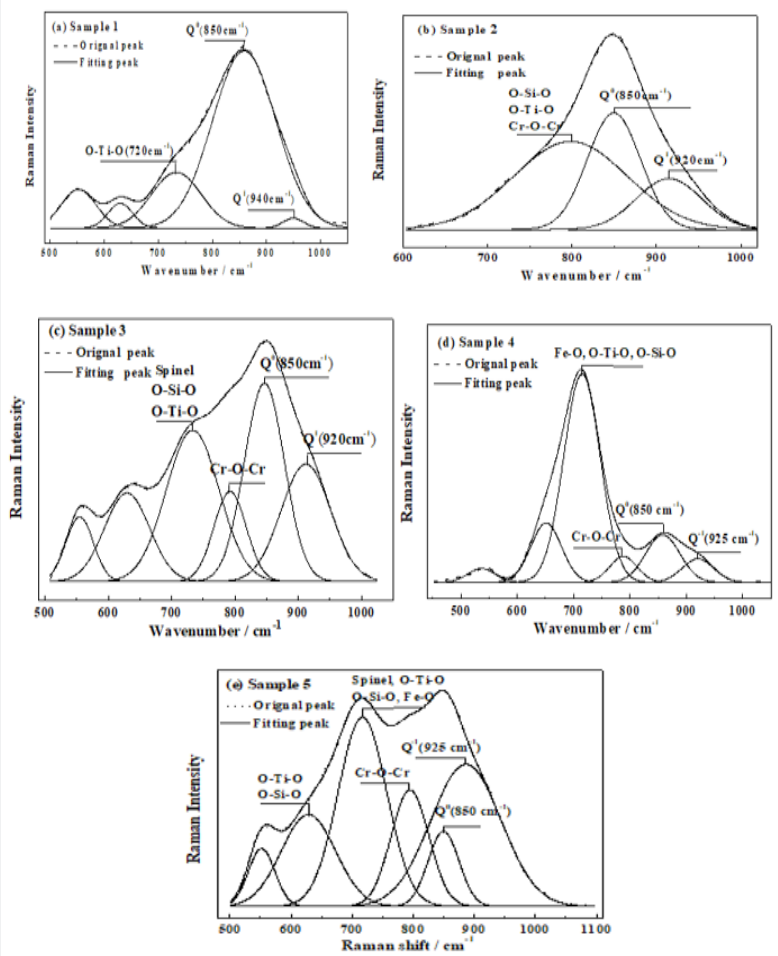

Figure 6: Deconvolved results of Raman spectra for samples with different $\mathrm{FeO}$ and $\mathrm{Cr}_{2} \mathrm{O}_{3}$ contents. 
Three possible structural roles of titanium in Ti-bearing glasses, suggested in previous reports, are considered: (1) $\mathrm{Ti}^{4+}$ substitutes for $\mathrm{Si}^{4+}$ in tetrahedral coordination in the structural units; (2) $\mathrm{Ti}^{4+}$ forms $\mathrm{TiO}_{2}$-like clusters in tetrahedral coordination; (3) $\mathrm{Ti}^{4+}$ as a network modifier possibly occurs in five-fold or sixfold coordination [25,30]. As can be seen from Figure 3 (samples 1-5), the second and third models can be employed to explain the results due to the fact that the band at about $600-750 \mathrm{~cm}^{-1}$ are detected in the glassy samples. It means that $\mathrm{Ti}^{4+}$ as a network modifier occurs in five-fold or six-fold coordination, which can significantly decrease the polymerization degree of silicates. And a small number of $\mathrm{Ti}^{4+}$ can form $\mathrm{TiO}_{2}$-like clusters in tetrahedral coordination. In addition, as the first model stated, $\mathrm{Ti}^{4+}$ is substituted for $\mathrm{Si}^{4+}$ in tetrahedral coordination in structural units of the glassy slags, the number of average bridging oxygen will be significantly increased and reaches about 2 for samples with about $10 \mathrm{wt} \% \mathrm{TiO}_{2}$ in the slag, and the polymerization degree of the silicates will be significantly enhanced according to Li's study and Huang's study [25,44]. Accordingly, the first model cannot consistently predict the number of average bridging oxygen of silicates with the present results, as listed in Table 5. The second and the third models are the most appropriate to describe the role of titanium in structure.

With the introduction of $1.5 \mathrm{wt} \% \mathrm{CaO}-\mathrm{SiO}_{2}-\mathrm{Al}_{2} \mathrm{O}_{3}-\mathrm{MgO}$ $\mathrm{TiO}_{2}$ system for sample 2, the main bands are hardly changed compared with sample 1 . However, the band about $720 \mathrm{~cm}^{-1}$ is shifted to about $780 \mathrm{~cm}^{-1}$ and its peak width increases due to the coexistence bands of $\mathrm{Cr}-\mathrm{O}-\mathrm{Cr}$ (about $730-750 \mathrm{~cm}^{-1}$ ), O-Si-O or O-Ti-O (about $600-750 \mathrm{~cm}^{-1}$ ) and $\mathrm{Cr}-\mathrm{O}$ (about $840-850 \mathrm{~cm}^{-1}$ ) [45-47]. Meanwhile the band about $920 \mathrm{~cm}^{-1}$ is enhanced and its peak width obviously increases. On this basis, with introduction of $5 \mathrm{wt} \% \mathrm{FeO}$ in $\mathrm{CaO}-\mathrm{SiO}_{2}-\mathrm{Al}_{2} \mathrm{O}_{3}-\mathrm{MgO}_{-} \mathrm{TiO}_{2}-1.5 \mathrm{wt} \% \mathrm{Cr}_{2} \mathrm{O}_{3}$ system for sample 3 , the Raman spectrum is obviously changed. The band at about $720 \mathrm{~cm}^{-1}$ appears again and its peak intensity and width are increased, which is considered to be the coexistence bands of $\mathrm{FeCr}_{2} \mathrm{O}_{4}$ (about $670 \mathrm{~cm}^{-1}$ ), O-Si-O or O-Ti-O $\left(600-750 \mathrm{~cm}^{-1}\right)$ $[46,48,49]$. The band about $780 \mathrm{~cm}^{-1}$ is considered the coexistence bands of Cr-O (about $840-850 \mathrm{~cm}^{-1}$ ) and $\mathrm{Cr}-\mathrm{O}-\mathrm{Cr}$ (about 730-750 $\mathrm{cm}$ $\left.{ }^{1}\right),[45,46]$ and its peak becomes narrower compared with sample 2 due to the formation of crystal phases (spinels). With further increasing 10 wt $\% \mathrm{FeO}$ in $\mathrm{CaO}-\mathrm{SiO}_{2}-\mathrm{Al}_{2} \mathrm{O}_{3}-\mathrm{MgO}^{-\mathrm{TiO}_{2}}-1.5 \mathrm{wt} \% \mathrm{Cr}_{2} \mathrm{O}_{3}$ slag for sample 4 , the peak of coexistence band at about 710 $\mathrm{cm}^{-1}$ is strengthened and other peaks are weakened due to the fact that the addition of $\mathrm{FeO}$ is disintegrated into $\mathrm{Fe}^{2+}$ (with main band about $710 \mathrm{~cm}^{-1}$ ) and $\mathrm{O}^{2-}$, which will impede the formation of complex chains ( $\mathrm{Q}^{1}$ and $\mathrm{Cr}-\mathrm{O}-\mathrm{Cr}$ ) and the crystallization of spinels in molten slag $[37,38,45,46]$. With further increasing $3 \mathrm{wt} \% \mathrm{Cr}_{2} \mathrm{O}_{3}$ in $\mathrm{CaO}-\mathrm{SiO}_{2}-\mathrm{Al}_{2} \mathrm{O}_{3}-\mathrm{MgO}-\mathrm{TiO}_{2}-10 \mathrm{wt} \% \mathrm{FeO}$ slag for sample 5 , the peaks of bands about 800 and $920 \mathrm{~cm}^{-1}$ are obviously enhanced, and the plenty of spinels are formed in molten slag. The plenty of the $\mathrm{Cr}-\mathrm{O}$ $\mathrm{Cr}$ bands are the consequence of the constraints imposed by their membership of a ring structure, which includes $\mathrm{Cr}-\mathrm{O}-\mathrm{Cr}$ and $\mathrm{Si}-\mathrm{O}-$ Si bonds [47]. Meanwhile, according to previous reports, $[45,48]$ $\mathrm{SiO}_{2}$ can stabilize the supported $\mathrm{Cr}^{3+}$ in tetrahedral coordination to enhance the ring structure. According to the Raman analysis, it is known that the crystal phases can form in $\mathrm{CaO}-\mathrm{SiO}_{2}-\mathrm{Al}_{2} \mathrm{O}_{3}-\mathrm{MgO}$ $\mathrm{TiO}_{2}-\mathrm{Cr}_{2} \mathrm{O}_{3}-\mathrm{FeO}$ system slags for sample 3 and sample 5 as shown in Figure 3. The crystal phases are mainly spinel phase $\left(\mathrm{MgCr}_{2} \mathrm{O}_{4}\right.$, $\mathrm{FeCr}_{2} \mathrm{O}_{4}$, with main bands about $670 \mathrm{~cm}^{-1}$ ), which is consistent with XRD and SEM/ EDX analysis.

The bands at $830-1000 \mathrm{~cm}^{-1}$ corresponds to the silicate sites for $Q^{0}, Q^{1}, Q^{2}$, and $Q^{3}$ structure units, $[25,31]$ as shown in Table 3. Considering that the molar fractions of different structure units are related to the band areas, all samples are deconvolved using the Gauss-Deconvolution method by assuming contribution from the structural units of $\mathrm{Q}^{\mathrm{n}}$ with the minimum correlation coefficient $\mathrm{r}_{2} \geq 0.99$ to study the effect of different components. Different $\mathrm{Q}^{\mathrm{n}}$ species can be described as follows

$$
Q^{n}=Q^{n+1}+Q^{n-1}
$$

As the scattering coefficients $\left(\theta_{n}\right)$ of $Q^{n}$ are different in the Raman spectrum as listed in Table 4, the mole fraction of the silicate structure units can be calculated as $[31,36]$

$$
x_{\mathrm{n}}=\theta_{n} \cdot A_{\mathrm{n}}
$$

Table 4: Coefficient of scattering of $Q^{n}$.

\begin{tabular}{|c|c|c|c|c|}
\hline$Q^{\mathrm{n}}$ & $\mathrm{Q}^{0}$ & $\mathrm{Q}^{1}$ & $\mathrm{Q}^{2}$ & $\mathrm{Q}^{3}$ \\
\hline$\theta_{\mathrm{n}}$ & 1 & 0.514 & 0.242 & 0.09 \\
\hline
\end{tabular}

where $x_{n}$ is the mole fraction of the silicate structure units, An is the area fraction of each structural unit [31]. The number of non-bridging oxygen in the silicate slag can be obtained as follows[31,36]

$$
n\left(\frac{\mathrm{NBO}}{T}\right)=\sum x_{n} \cdot(4-n)
$$

Where $n(\mathrm{NOB} / \mathrm{T})$ is the number of non-bridging oxygen in the silicate slags. In addition, the average number of bridging oxygen in each sample is also used to explain the change of the silicate structures in melts, which can be estimated by the area ratio of each structural unit $\left(Q^{n}\right)$ multiplied by the number of its bridging oxygen. The best-fit simulations are conducted by the GaussDeconvolution method. The summary of the deconvolution and calculation results is listed in Table 5. 
Academic Journal of Polymer science

Table 5: Deconvolved results of Raman spectra for $\mathrm{CaO}-\mathrm{SiO}_{2}-\mathrm{Al}_{2} \mathrm{O}_{3}-\mathrm{MgO}-\mathrm{TiO}_{2}-\mathrm{Cr}_{2} \mathrm{O}_{3}-\mathrm{FeO}$ slag.

\begin{tabular}{|c|c|c|c|c|c|c|}
\hline Sample No. & $\mathbf{Q}^{\mathbf{0} \%}$ & $\mathbf{Q}^{\mathbf{1} \%}$ & $\mathbf{Q}^{2 / \%}$ & $\mathbf{Q}^{3 / \%}$ & The average bridging oxygen & $\mathbf{n}(\mathbf{N B O} / \mathbf{T})$ \\
\hline 1 & 98.21 & 1.79 & 0 & 0 & 0.018 & 3.956 \\
\hline 2 & 64.963 & 35.037 & 0 & 0 & 0.35 & 3.139 \\
\hline 3 & 57.707 & 42.293 & 0 & 0 & 0.423 & 2.96 \\
\hline 4 & 69.763 & 31.237 & 0 & 0 & 0.312 & 3.232 \\
\hline 5 & 18.795 & 81.205 & 0 & 0 & 0.812 & 2.004 \\
\hline
\end{tabular}

As can be seen from Table 5, the change of the number of nonbridging oxygen is contrary to the average number of bridging oxygen, which verifies the accuracy of the calculation results. Table 5 also shows that the number of non-bridging oxygen rapidly decreases when increasing $\mathrm{Cr}_{2} \mathrm{O}_{3}$ from 0 to $1.5 \mathrm{wt} \%$ in the slag, which can be explained by the reason that $\mathrm{Cr}_{2} \mathrm{O}_{3}$ plays the role of forming chain to increase the polymerization degree of the silicate slag. This result indicates that the majority of $\mathrm{Cr}^{3+}$ will form the bands of $\mathrm{Cr}-\mathrm{O}-\mathrm{Cr}$ in tetrahedral coordination and can change the polymerization degree of the silicates. In addition, Table 5 also shows that the number of non-bridging oxygen slightly decreases as the content of $\mathrm{FeO}$ increases from 0 to $5 \mathrm{wt} \%$ for sample 3, indicating that the polymerization degree of silicates increases due to the increase of $\mathrm{Q}^{1}$ and spinels in the molten slag. With further increasing $10 \mathrm{wt} \% \mathrm{FeO}$ in the slag for sample 4, the number of non-bridging oxygen slightly increases due to the dissociation of the free cation $\left(\mathrm{Fe}^{2+}\right)$ and $\mathrm{O}^{2-}$ from $\mathrm{FeO}$ to interrupt the chain structures (Cr-O-Cr, Ti-O-Ti and Si-O-Si). With further introduction of $3 \mathrm{wt} \% \mathrm{Cr}_{2} \mathrm{O}_{3}$ in slag for sample 5 , the polymerization degree of silicate increases and the number of non-bridging oxygen obviously decreases due to the formation of solid spinel and $\mathrm{Cr}$ $\mathrm{O}-\mathrm{Cr}$ in the chain structure. As the field strength (change/radius) of the cations is $\mathrm{Si}^{4+}>\mathrm{Cr}^{3+}>\mathrm{Al}^{3+}>\mathrm{Ti}^{4+}$, the bond lengths of $\mathrm{Si}-\mathrm{O}, \mathrm{Cr}-\mathrm{O}$, Al-O Ti-O, and Fe-O are 1.63, 1.65, 1.81, 1.94, 2.16 , respectively $[25,45,50]$. The combined capacity between the cations and $02-$ is also presented by comparing their bond length; the ranks of the stability are $\mathrm{Si}-\mathrm{O}>\mathrm{Cr}-\mathrm{O}>\mathrm{Al}-\mathrm{O}>\mathrm{Ti}-\mathrm{O}$, which is opposite to their band length, as proposed by Zhang, Hino, and Baddour-Hadjean's studies $[31,45,50]$. Thus, it can be concluded that $\mathrm{FeO}$ and $\mathrm{TiO}_{2}$ in slag can break up the 3-dimensional networks and the chain structures formed by Si and 0, and hamper the crystallization of spinels, which is consistent with the conclusion proposed in Park's work [25].

From above analysis, the spinel phases only form in the sample 3 and 5 for the $\mathrm{Cr}_{2} \mathrm{O}_{3}$-bearing $\mathrm{BF}$ vanadium system slag. In addition, the polymerization degree is low and the spinel $\left(\mathrm{MgCr}_{3} \mathrm{O}_{4}\right)$ does not form in $\mathrm{CaO}-\mathrm{SiO}_{2}-\mathrm{Al}_{2} \mathrm{O}_{3}-\mathrm{MgO}-\mathrm{TiO}_{2}-1.5 \mathrm{wt} \%$ $\mathrm{Cr}_{2} \mathrm{O}_{3}$ slag due to the existence of a large amount of $\mathrm{TiO} 2$ in the slag, which can decrease as a chain structure, increase a number of discrete Si-O-Ti as well as Ti-O-Ti structural units to hamper the crystallization of $\mathrm{MgCr}_{2} \mathrm{O}_{4}$ as the main crystal phase in the slag, and thus the viscosity of the system is lower than that of BF slag.
With introduction of $5 \mathrm{wt} \% \mathrm{FeO}$ in the system, a small amount of spinel (main of $\mathrm{FeCr}_{3} \mathrm{O}_{4}$ ) is formed due to the fact that the Gibbs free energy of $\mathrm{FeCr}_{2} \mathrm{O}_{4}$ formation is lower and its molecular binding force is stronger, compared with that of $\mathrm{MgCr}_{2} \mathrm{O}_{4}$. On the other hand, the formation of $\mathrm{FeCr}_{2} \mathrm{O}_{4}$ offers the crystal nucleus to promote the production of $(\mathrm{Mg}, \mathrm{Fe})(\mathrm{Cr}, \mathrm{Al})_{2} \mathrm{O}_{4}$ and $\mathrm{Ca}_{3} \mathrm{Mg}\left(\mathrm{SiO}_{4}\right)_{2}$ in the system. On the contrary, the polymerization degree becomes weaker and spinels disappear with increasing $\mathrm{FeO}$ from $5 \mathrm{wt} \%$ to $10 \mathrm{wt} \%$ due to an increased number of $\mathrm{Fe}^{2+}$, oxygen ion $\left(\mathrm{O}^{2-}\right)$ and discrete $\mathrm{Si}-\mathrm{O}-\mathrm{Ti}$ as well as Ti-O-Ti structural units, which will break the chain structure and hamper the crystallization of spinels $\left(\mathrm{MgCr}_{2} \mathrm{O}_{4}, \mathrm{FeCr}_{2} \mathrm{O}_{4}, \mathrm{MgAl}_{2} \mathrm{O}_{4}\right.$ and $\left.\mathrm{FeAl}_{2} \mathrm{O}_{4}\right)$ in the slag [46]. Furthermore, the crystallization ability of the $\mathrm{SiO}_{2}-\mathrm{TiO}_{2}$ system will decrease with increasing of $\mathrm{TiO}_{2}$ according to Dines's study [45]. $\mathrm{SiO}_{2}$ and $\mathrm{Cr}_{2} \mathrm{O}_{3}$ can form liquid slag at temperature above $1573 \mathrm{~K}$ according to Healy and Schottmiller's suggestion.[51] And $\mathrm{TiO}_{2}$ can increase the solubility of $\mathrm{Cr}_{2} \mathrm{O}_{3}$ in $\mathrm{FeO}-\mathrm{SiO}_{2}-\mathrm{V}_{2} \mathrm{O}_{3}-\mathrm{Cr}_{2} \mathrm{O}_{3}-$ $\mathrm{TiO}_{2}$ system slag according to Huang revelation [44]. According to this study, it knows that the existence of plenty of $\mathrm{TiO}_{2}$ and $\mathrm{FeO}$ in the $\mathrm{CaO}-\mathrm{SiO}_{2}-\mathrm{Al}_{2} \mathrm{O}_{3}-\mathrm{MgO}-\mathrm{TiO}_{2}-\mathrm{Cr}_{2} \mathrm{O}_{3}-\mathrm{FeO}$ slag can hamper the formation of spinels when the content of $\mathrm{Cr}_{2} \mathrm{O}_{3}$ is low in the molten slag. So the spinels do not form in the samples 2 and 4 .

Correlation between the structural information and physiochemical properties of $\mathrm{Cr}_{2} \mathrm{O}_{3}$-bearing $\mathrm{BF}$ vanadium slag will naturally be expected. Many researchers have reported that the viscosity and melting temperature of the slag increase with an increase of $\mathrm{w}\left(\mathrm{Cr}_{2} \mathrm{O}_{3}\right)$ and decrease with an increase of $\mathrm{w}(\mathrm{FeO})$ and $\mathrm{w}\left(\mathrm{TiO}_{2}\right)[15,25]$. According to the present study, the polymerization degree drastically increases with $\mathrm{Cr}_{2} \mathrm{O}_{3}$ introduction because of the formation of $\mathrm{Cr}-\mathrm{O}-\mathrm{Cr}$ in chain structures and the high meltingpoint spinel $\left(\mathrm{FeCr}_{2} \mathrm{O}_{4}\right.$, with the melting temperature about 2273 $\mathrm{K})$ in this system. According to the literature,[30,35] if the high melting-point solid exists in the liquid, it not only affects the homogenized liquid but also forms the plenty of solid-liquid phase interface in molten slag to dramatically increase internal friction, which will significantly increase the slag viscosity. Thus it is considered that the bond of $\mathrm{Cr}-\mathrm{O}-\mathrm{Cr}$ and the precipitation of spinels may affect the slag viscosity, but the effect of spinels is greater than that of the $\mathrm{Cr}-\mathrm{O}-\mathrm{Cr}$ bond. On the contrary, when existing an amount of $\mathrm{FeO}$ and $\mathrm{TiO}_{2}$ in the slag, the polymerization degree will decrease due to a decrease of as a chain structure and an increased number of discrete $\mathrm{Si}-\mathrm{O}-\mathrm{Ti}$ as well as Ti-O-Ti 
structural units, which can hamper the crystallization of $\mathrm{FeCr}_{2} \mathrm{O}_{4}$ as the main crystallization product in the $\mathrm{CaO}-\mathrm{MgO}-\mathrm{SiO}_{2}-\mathrm{Al}_{2} \mathrm{O}_{3}$ $\mathrm{TiO}_{2}-\mathrm{FeO}-\mathrm{Cr}_{2} \mathrm{O}_{3}$ system, thus the viscosity of system can decrease.

\section{Conclusion}

The melt structure and property of CaO-MgO- $\mathrm{SiO}_{2}-\mathrm{Al}_{2} \mathrm{O}_{3}$ $\mathrm{TiO}_{2}$ system with varied $\mathrm{FeO}$ and $\mathrm{Cr}_{2} \mathrm{O}_{3}$ contents are investigated by the rotating cylinder method and Raman spectroscopy, respectively. Based on the above results, the following conclusions have been drawn:

a. The viscosity of the $\mathrm{CaO}-\mathrm{MgO}-\mathrm{SiO}_{2}-\mathrm{Al}_{2} \mathrm{O}_{3}-\mathrm{TiO}_{2}$ system is decreased to $1.5 \mathrm{~Pa} \cdot \mathrm{s}$ at temperatures above $1565 \mathrm{~K}$. With the introduction of $1.5 \mathrm{wt} \% \mathrm{Cr}_{2} \mathrm{O}_{3}$ and $5 \mathrm{wt} \% \mathrm{FeO}$ into $\mathrm{CaO}-\mathrm{MgO}$ $\mathrm{SiO}_{2}-\mathrm{Al}_{2} \mathrm{O}_{3}-\mathrm{TiO}_{2}$ system, the viscosity significantly increases and is decreased to $1.5 \mathrm{~Pa} \cdot \mathrm{s}$ until temperature higher than $1640 \mathrm{~K}$. With further increasing $10 \mathrm{wt} \% \mathrm{FeO}$ into the $\mathrm{CaO}-\mathrm{MgO}-\mathrm{SiO}_{2}-$ $\mathrm{Al}_{2} \mathrm{O}_{3}-\mathrm{TiO}_{2}-1.5 \mathrm{wt} \% \mathrm{Cr}_{2} \mathrm{O}_{3}$ system, the viscosity decreases and is $1.5 \mathrm{~Pa} \cdot \mathrm{s}$ at about $1620 \mathrm{~K}$. However, the viscosity increases again after the increase of $\mathrm{Cr}_{2} \mathrm{O}_{3}$ to $3 \mathrm{wt} \%$ in the $\mathrm{CaO}-\mathrm{MgO}-\mathrm{SiO}_{2}-\mathrm{Al}_{2} \mathrm{O}_{3}-$ $\mathrm{TiO}_{2}-10 \mathrm{wt} \% \mathrm{FeO}$ system, the viscosity is decreased to $1.5 \mathrm{~Pa} \cdot \mathrm{s}$ until temperature higher than $1680 \mathrm{~K}$.

b. $\mathrm{Ti}^{4+}$ mainly exists in the form of discrete $\mathrm{Si}-\mathrm{O}-\mathrm{Ti}$ and $\mathrm{Ti}-$ O-Ti as monomer which hampers the crystallization of $\mathrm{FeCr}_{2} \mathrm{O}_{4}$ in the molten slag and decreases the polymerization degree of the $\mathrm{CaO}-\mathrm{MgO}-\mathrm{SiO}_{2}-\mathrm{Al}_{2} \mathrm{O}_{3}-\mathrm{TiO}_{2}-\mathrm{FeO}-\mathrm{Cr}_{2} \mathrm{O}_{3}$ system. Most of $\mathrm{Cr}^{3+}$ exists in the bond of $\mathrm{Cr}-\mathrm{O}-\mathrm{Cr}$ to form network structures, and part of the chromium exists in the form of solid spinels, which can dramatically enhance the polymerization degree of the system slag. $\mathrm{FeO}$ should disintegrate into $\mathrm{Fe}^{2+}$ and $\mathrm{O}^{2-}$ to decrease the polymerization degree of the slag. Furthermore, part of $\mathrm{FeO}$ can form spinels when $\mathrm{Cr}_{2} \mathrm{O}_{3}$ exists in the slag to obviously increase the polymerization degree of the slag.

c. The polymerization degree of silicate structures is lower in the $\mathrm{CaO}-\mathrm{MgO}-\mathrm{SiO}_{2}-\mathrm{Al}_{2} \mathrm{O}_{3}-\mathrm{TiO}_{2}$ system due to the main existence of $\mathrm{Q}^{0}$ as a monomer structure in the slag. With the introduction of 1.5 wt $\% \mathrm{Cr}_{2} \mathrm{O}_{3}$ into the $\mathrm{CaO}-\mathrm{MgO}-\mathrm{SiO}_{2}-\mathrm{Al}_{2} \mathrm{O}_{3}-\mathrm{TiO}_{2}$ system, the polymerization degree of the silicate structure is enhanced due to the formation of $\mathrm{Q}^{1}$ in a chain structure. With the introduction of 5 wt $\% \mathrm{FeO}$ into the $\mathrm{CaO}-\mathrm{MgO}-\mathrm{SiO}_{2}-\mathrm{Al}_{2} \mathrm{O}_{3}-\mathrm{TiO}_{2}-1.5 \mathrm{wt} \% \mathrm{Cr}_{2} \mathrm{O}_{3}$ system, the polymerization degree of silicate significantly increases due to the increase of $\mathrm{Q}^{1}$ and spinels in the slag. With further increasing $10 \mathrm{wt} \% \mathrm{FeO}$ in the $\mathrm{CaO}-\mathrm{MgO}-\mathrm{SiO}_{2}-\mathrm{Al}_{2} \mathrm{O}_{3}-\mathrm{TiO}_{2}-1.5 \mathrm{wt} \% \mathrm{Cr}_{2} \mathrm{O}_{3}$ system, the polymerization degree decreases and spinel disappears. When increasing $\mathrm{Cr}_{2} \mathrm{O}_{3}$ to $3 \mathrm{wt} \%$ in the $\mathrm{CaO}-\mathrm{MgO}-\mathrm{SiO}_{2}-\mathrm{Al}_{2} \mathrm{O}_{3}$ $\mathrm{TiO}_{2}-10 \mathrm{wt} \% \mathrm{FeO}$ system, spinels appear again and transform into $\mathrm{Fe}(\mathrm{Al}, \mathrm{Cr})_{2} \mathrm{O}_{4}$, and the polymerization degree of the slag obviously increases.

\section{Acknowledgment}

The work was supported by the National Natural Science Foundation of China (No. 51804094), the Iron and Steel Joint
Foundation of Hebei Province (E2020402016), Funding Project of Overseas Returnees from Hebei Province (C201806), and Open Topic of Key Laboratory of Material Forming and Structure Property Control from University of Science and Technology Liaoning (USTLKFSY201708).

\section{References}

1. Li XS, Xie B (2012) Int J Miner Metall Mater 19: 595-601.

2. Zhang X, Xie B, Diao J, Li XJ (2012) Ironmak Steelmak 39: 147.

3. Huang WJ, Chen M, Shen X, Yu S, Wang N, et al. (2017) Steel Res Int 88: 1.

4. Huang WJ, Yu S, Shen X, Xu L, Wang N, et al. (2016) Steel Res Int 87: 1228.

5. Wu XR, Li LS, Dong YC (2007) ISIJ Int 47: 402.

6. Dong YC, Wu XR, Li LS (2005) ISIJ Int 45: 1238.

7. Liu B, Du H, Wang SN, Zhang Y, Zheng SL, et al. (2013) AIChE J 59: 541.

8. Fang HX, Li HY, Xie B (2012) ISIJ Int 52: 958.

9. Zhang SQ, Xue B, Wang Y, Guan T, Cao HL, et al. (2012) J Iron Steel Res Int 19: 33 .

10. Yu L, Dong YC, Ye GZ, Du SC (2007) Ironmak Steelmak 34: 131.

11. Zeng L, Wang Y, Fan LK, Xie B (2014) J Iron Steel Res Int 21: 910.

12. Diao J, Xie B, Ji CQ Guo X, Wang YH, et al. (2009) Cryst Res Technol 44: 707.

13. Lenaz D, Lughi V (2013) Phys Chem Miner 40: 491.

14. Otero LR, Weber MC, Thomas PA, Kreisel J, Salgueiriño V (2010) Phys Chem Chem Phys 16: 22337.

15. Mougin J, Rosman N, Lucazeau G, Galerie A (2001) J Raman Spectrosc 32: 739.

16. Diao J, Xie B, Wang Y, Ji CQ (2009) Ironmak. Steelmak 36: 476.

17. Wu SL, Xu J, Yang SD, Zhou Q Zhang LH (2010) ISIJ Int 50: 1032.

18. Zhao W, Chu MS, Wang HT, Liu ZG, Tang J, et al. (2018) ISIJ Int 58: 823.

19. Fang HX, Li HY, Zhang T, Liu BS, Xie B (2015) ISIJ Int 55: 200.

20. Chu MS, Nogami H, Yagi JI (2004) ISIJ Int 44: 801.

21. Zuo GQ (2000) ISIJ Int 40: 1195.

22. Ökvist LS (2001) The Melting Properties of Tuyere Slags with and without Flux Injection into the Blast Furnace. ISIJ Int 41(12): 14291436.

23. Ökvist LS, Cang D, Zong Y, Ball H (2004) ISIJ Int 44: 1501.

24. Li LS, Wu XR, Yu L, Dong YC (2008) Ironmak Steelmak 35: 367.

25. Li JL, Shu QF, Chou K (2014) ISIJ Int 54: 721.

26. Mills KC, Yuan L, Jones RT (2011) Afr Inst Min Metall 111: 649.

27. Vedishcheva NM, Shakhmatkin BA, Wright AC (2001) J NonCryst Solids 293: 312.

28. Zhang Y, Tang J, Chu MS, Liu Y, Chen SY, et al. (2014) J Iron Steel Res Int 21: 144 .

29. Ostrovski OI, Utochkin YI, Pavlov AV, Akberdin RA (1994) ISIJ Int 34: 773.

30. Huang XG (2010)Principles of Steel Metallurgy, Metallurgical Industry Press, China, p. 168. 
31. Maria C, Marek L, Tadeas G, Jan M (2014) J Therm Anal Calorim 118: 835.

32. Yang J, Cheng HF, Martens WN, Frost RL (1069) J Raman Spectrosc 42: 1069.

33. Shankar A, Gornerup M, Lahiri AK, Seetharaman S (2007) Metall Mater Trans B 38: 911.

34. Saito N, Hori N, Nakashima K, Mori K (2003) Viscosity of blast furnace type slags. Metall Mater Trans B 34: 509-561.

35. Qian YW, Zhai XJ, Lui KR (2007) Physical Chemistry of Metallurgy, Chemical Industry Press, China, p. 124

36. Huang DX (2000) Vanadium Extraction and Steelmaking, Metallurgical Industry Press, China, p. 56.

37. Ishibashi H, Arakawa M, Yamamoto J, Kagi H (2012) J Raman Spectrosc 43: 331 .

38. Muralha VSF, Rehren T, Clark RGH (2011) J Raman Spectrosc 42: 2077.

39. Zhang SF, Zhang X, Bai CG, Wen LY, Lv XW (2013) ISIJ Int 53: 1131.

40. Park H, Park JY, Kim H, Sohn I (2012) Effect of $\mathrm{TiO}_{2}$ on the viscosity and slag structure in blast furnace type slags. Steel Res Int 83(2): 150-156.

41. Faria de DLA, Silva SV, Oliveira de MT (1997) J Raman Spectrosc 28: 873
42. Whittaker L, Velazquez JM, Banerjee S (2011) A VO-seeded approach for the growth of star-shaped $\mathrm{VO}_{2}$ and V205nanocrystals: facile synthesis, structural characterization, and elucidation of electronic structure. CrystEngComm 13: 5328.

43. Chen XB, Shin JH, Kim HT, Lim YS (2012) J Raman Spectrosc 43: 2025.

44. Huang WJ, Zhao YH, Yu S, Zhang LX, Ye ZC, et al. (2016) ISIJ Int 56: 594

45. Dines TJ, Inglis S (2003) Raman spectroscopic study of supported chromium(vi) oxide catalysts. Phys Chem Phys 5(6): 1320-1328.

46. Taran MN, Parisi F, Lenaz D, Vishnevskyy A(2014) Phys Chem Miner 41: 593.

47. Albertsson G, Teng LD, Bjorkman B, Seetharaman S, Engstrom F (2013) Steel Res Int 84: 670.

48. Dong PL, Wang XD, Seetharaman S (2002) Steel Res Int 80: 202.

49. Li JL, Xu AJ, He DF, Yang QX, Tian NY (2013) Int J Miner Metall Mater 20: 253.

50. Hadjean RB, Golabkan V, Pereira-Ramos JP, Mantoux A, Lincot J (2002) Raman Spectrosc 33: 631

51. Itoh T, Nagaska T, Hino M (2002) Thermodynamics of Oxygen in Liquid $\mathrm{Fe}-\mathrm{Cr}$ Alloy Saturated with $\mathrm{FeO} \cdot \mathrm{Cr}_{2} \mathrm{O}_{3}$ Solid Solution. ISIJ Int 42(1): 33

Your next submission with Juniper Publishers will reach you the below assets

- Quality Editorial service

- Swift Peer Review

- Reprints availability

- E-prints Service

- Manuscript Podcast for convenient understanding

- Global attainment for your research

- Manuscript accessibility in different formats ( Pdf, E-pub, Full Text, Audio)

- Unceasing customer service

Track the below URL for one-step submission

https://juniperpublishers.com/online-submission.php 